\title{
MODELING OF THE OPTICAL FILTERS ON DIFFERENT WGM DISK MICRORESONATORS
}

\author{
Alexander A. Trubin \\ The Institute of Telecommunication Systems \\ Igor Sikorsky Kyiv Politechnic Institute, Kyiv, Ukraine
}

Background. At the present time, further increase in the speed of processing and transmission of information is associated with the development of hybrid integrated circuits, combining electrical and optical components. One of the important constituent parts of future optical integrated circuits are filters that can be conveniently implemented using so-called disc microresonators with whispering gallery oscillations.

Technically, the problem of manufacturing such filters in the infrared and even in the visible wavelength range has been solved, but calculation of parameters and tuning of multilink filters is impossible without further development of the theory of their building. The development of such a theory is based on the electrodynamic modeling of processes that occur in complex systems of coupled microcavities, coupled also with transmission line. At present, the study of filters built on different microresonators has not been carried out.

Objective. The aim of the research is to construct the theory of scattering of electromagnetic waves of the integral optical transmission lines on systems of coupled different optical microresonators with whispering gallery modes.

Development of mathematical models of filters constructed using various disk microresonators. Investigation of new structures of coupled microresonators with acceptable scattering characteristics.

Methods. To construct a mathematical model of filters, an approximate solution of the Maxwell equations based on perturbation theory is used. The application of perturbation theory made it possible to find a solution to the problem of calculating the S-matrix of the filter in an analytical form.

Results. An electrodynamic model for the scattering of optical transmission line waves by a system of different shapes coupled microresonators and made of different dielectrics is developed. New structures of microresonators, realizing bandpass and bandstop filters, are investigated and their scattering characteristics are calculated.

Conclusions. The theory of scattering of electromagnetic waves by systems of various coupled optical microresonators is expanded. A new definition of the coupling coefficients of different microresonators is given. New models of filters are constructed.

Keywords: infrared range; integrated optics; optical filter; bandstop filter; bandpass filter; microresonator.

\section{Introduction}

Whispering-gallery-mode (WGM) microresonators are used in filters, switches and laser stabilizing elements of the optical communication devices [1].

It's known that in addition to a very high $\mathrm{Q}$ factor the dielectric microresonators have a such disadvantage, as increased density of the spectrum. The scattering parameters of a variety of the optical devices can be significantly improved by using microresonators of different forms [2-6]. In the early works, for the theory simplification, all microresonators are generally supposed to have the same shape and manufactured of the same dielectric. In order to improve the scattering parameters in some cases there is need to build filters on microresonators with different shapes made of various dielectrics. However, in this case theory describing scattering processes becomes more complicated. In this article the system of equations describing different microresonators have been developed. Total analytical solution has been found. In special case of identical microresonators obtained solutions are simplified to the known ones [7].

By using obtained equations, the research of electromagnetic wave scattering problem on different microresonator structures have been conducted in the propagating optical waveguide and between two waveguide segments. A new design of both the bandstop and bandpass filters on different Disk Microresonators are examined.

\section{Statement of the problem}

The goal of the current article is the development of the theory of optical filters, consisting of different microresonators, that can be used in the modern communication systems. 


\section{Scattering theory}

Consider the system of $\mathrm{N}$ different microresonators, consisting of different materials. We assumed that the eigenoscillation field of each isolated microresonator is known: $\left(\overrightarrow{\mathrm{e}}_{\mathrm{s}}, \overrightarrow{\mathrm{h}}_{\mathrm{s}}\right),(\mathrm{s}=1,2, \ldots, \mathrm{N})$. Here $\overrightarrow{\mathrm{e}}_{\mathrm{s}}$-is the electric field and $\overrightarrow{\mathrm{h}}_{\mathrm{s}}$ - is the magnetic field intensity of the $\mathrm{s}$-th isolated microresonator. The eigenoscillation field of the $\mathrm{N}$ - microresonator system $(\overrightarrow{\mathrm{e}}, \overrightarrow{\mathrm{h}})$ can be found as a superposition of fields of the isolated resonators:

$$
\overrightarrow{\mathrm{e}}=\sum_{\mathrm{s}=1}^{\mathrm{N}} \mathrm{b}_{\mathrm{s}} \overrightarrow{\mathrm{e}}_{\mathrm{s}} ; \quad \overrightarrow{\mathrm{h}}=\sum_{\mathrm{s}=1}^{\mathrm{N}} \mathrm{b}_{\mathrm{s}} \overrightarrow{\mathrm{h}}_{\mathrm{s}}
$$

The amplitudes $b_{s}$ should satisfy the equation system [7]:

$$
\sum_{s=1}^{N}\left(k_{s n}+i \tilde{k}_{s n}\right) b_{s}-\lambda b_{n}=0,(n=1,2, \ldots, N)
$$

where

$$
\lambda=2 \cdot\left(\delta \omega / \omega_{0}+i \omega^{\prime \prime} / \omega_{0}\right) ;
$$

$\delta \omega=\operatorname{Re}\left(\tilde{\omega}-\omega_{0}\right) ; \quad \omega^{\prime \prime}=\operatorname{Im}(\tilde{\omega}) ; \mathrm{k}_{\mathrm{sn}}, \quad \tilde{\mathrm{k}}_{\mathrm{sn}}$ are the coupling coefficients on the damped and expanding waves of the transmission line; $\omega_{0}=\operatorname{Re}\left[\omega_{\mathrm{s}}\right]$ is the real part of frequencies of isolated partial resonators $(\mathrm{s}=1,2, \ldots, \mathrm{N})$. In the case of different microresonator shapes the coupling coefficients take different views: $\mathrm{k}_{\mathrm{sn}} \neq \mathrm{k}_{\mathrm{ns}}$ and $\tilde{\mathrm{k}}_{\mathrm{sn}} \neq \tilde{\mathrm{k}}_{\mathrm{ns}}$ :

$$
\begin{aligned}
& \mathrm{k}_{\mathrm{sn}}=\frac{-1}{\omega_{0} \mathrm{w}_{\mathrm{n}}} \sum_{\mathrm{t} \geq \mathrm{t}_{\mathrm{M}}}\left(\mathrm{c}_{\mathrm{t}}^{\mathrm{s} \pm}\right)_{0}\left(\mathrm{c}_{\mathrm{t}}^{\mathrm{n} \mp}\right)_{0}^{*} \mathrm{e}^{-\Gamma\left|\mathrm{z}_{\mathrm{s}}-\mathrm{z}_{\mathrm{n}}\right|} ; \\
& \tilde{\mathrm{k}}_{\mathrm{sn}}=\frac{1}{\omega_{0} \mathrm{w}_{\mathrm{n}}} \sum_{\mathrm{t} \leq \mathrm{t}_{\mathrm{M}}}\left(\mathrm{c}_{\mathrm{t}}^{\mathrm{s} \pm}\right)_{0}\left(\mathrm{c}_{\mathrm{t}}^{\mathrm{n} \pm}\right)_{0}^{*} \mathrm{e}^{-\mathrm{i} \Gamma\left|\mathrm{z}_{\mathrm{s}}-\mathrm{z}_{\mathrm{n}}\right|} .
\end{aligned}
$$

Here $t_{M}$ - is the ultimate multi index, determining the numbers of the expanding waves in the transmission line, and a $\left(\mathrm{c}_{\mathrm{t}}^{\mathrm{s} \pm}\right)_{0}-$ is the expansion coefficient of the $\mathrm{s}$-th microresonator field on the $\mathrm{t}$-th wave of the transmission line [7], calculated in the coordinate system, associated with $\mathrm{s}$-th resonator center; $z_{s}$ - is the longitudinal coordinate of $s$-th microresonator center; $\Gamma$ - is the longitudinal wave number of the transmission line; and $\mathrm{w}_{\mathrm{n}}=1 / 4 \int_{\mathrm{v}_{\mathrm{n}}}\left(\varepsilon_{1}\left|\overrightarrow{\mathrm{e}}_{1 \mathrm{n}}\right|^{2}+\mu_{0}\left|\overrightarrow{\mathrm{h}}_{1 \mathrm{n}}\right|^{2}\right) \mathrm{dv}-$ is the energy, stored in the dielectric of the $\mathrm{n}$-th microresonator $(\mathrm{s}, \mathrm{n}=1,2, \ldots, \mathrm{N})$.
Generally, by providing the solution to the equation system for each obtained $\lambda_{\mathrm{v}}(2)$, it is possible both to calculate approximately the complex frequencies $\tilde{\omega}^{v}$ of the system coupling oscillations and to determine all amplitudes of partial resonators $\overrightarrow{\mathrm{b}}^{\mathrm{v}}=\left(\mathrm{b}_{1}^{\mathrm{v}}, \mathrm{b}_{2}^{\mathrm{v}}, \ldots, \mathrm{b}_{\mathrm{N}}^{\mathrm{v}}\right),(\mathrm{v}=1,2, \ldots, \mathrm{N})$.

The problem solution of the waveguide wave $\left(\overrightarrow{\mathrm{E}}_{1}^{+}, \overrightarrow{\mathrm{H}}_{1}^{+}\right)$scattering on the microresonator system will be searched in the form of expansion on coupling modes:

$$
\overrightarrow{\mathrm{E}} \approx \overrightarrow{\mathrm{E}}_{1}^{+}+\sum_{\mathrm{s}=1}^{\mathrm{N}} \mathrm{a}^{\mathrm{s}} \overrightarrow{\mathrm{e}}^{\mathrm{s}} ; \quad \overrightarrow{\mathrm{H}} \approx \overrightarrow{\mathrm{H}}_{1}^{+}+\sum_{\mathrm{s}=1}^{\mathrm{N}} \mathrm{a}^{\mathrm{s}} \overrightarrow{\mathrm{h}}^{\mathrm{s}},
$$

where $\left(\overrightarrow{\mathrm{e}}^{\mathrm{s}}, \overrightarrow{\mathrm{h}}^{\mathrm{s}}\right)$ is the field of the $\mathrm{N}$ - microresonator system (1), corresponding to the eigenvalue $\lambda_{\mathrm{s}}$ (2).

By using perturbation theory, after the volume integration of each partial resonator after simplifications the equation system with the unknown coefficients $\mathrm{a}^{\mathrm{s}}$ has been obtained in the form:

$\sum_{\mathrm{s}=1}^{\mathrm{N}} \mathrm{a}^{\mathrm{s}} \mathrm{b}_{\mathrm{t}}^{\mathrm{s}} \mathrm{Q}_{\mathrm{st}}(\omega)=-\left(\mathrm{c}_{1}^{\mathrm{t}^{+}}\right)^{*} / \mathrm{P}_{\mathrm{t}}^{\mathrm{D}} ; \quad(\mathrm{t}=1,2, \ldots, \mathrm{N})$.

Where for different resonators, the functions $\mathrm{Q}_{\mathrm{st}}(\omega)$ are dependent on the partial and the coupled oscillation microresonator numbers:

$$
\mathrm{Q}_{\mathrm{st}}(\omega)=2 \mathrm{i} \frac{\omega-\tilde{\omega}^{\mathrm{s}}}{\omega_{0}} \mathrm{Q}_{\mathrm{t}}^{\mathrm{D}}+\frac{\omega}{\omega_{0}} ;
$$

$\mathrm{P}_{\mathrm{t}}^{\mathrm{D}}=\omega_{0} \frac{\varepsilon_{\mathrm{t}}^{\prime \prime}}{2} \int_{\mathrm{V}_{\mathrm{t}}}\left|\overrightarrow{\mathrm{e}}_{\mathrm{t}}\right|^{2} \mathrm{dv}$ - is the loss power in the dielectric of $\mathrm{t}$-th microresonator; $\mathrm{Q}_{\mathrm{t}}^{\mathrm{D}}=\omega_{0} \mathrm{w}_{\mathrm{t}} / \mathrm{P}_{\mathrm{t}}^{\mathrm{D}}$.

The transmission $\mathrm{T}$ and the reflection coefficient $\mathrm{R}$ of different microresonator system can be obtained from (4), (5) in the form:

$$
\begin{aligned}
& \mathrm{T}=\mathrm{T}_{0}+\sum_{\mathrm{u}=1}^{\mathrm{N}}\left(\sum_{\mathrm{s}=1}^{\mathrm{N}} \mathrm{b}_{\mathrm{s}}^{\mathrm{u}} \mathrm{c}_{\mathrm{s}}^{+}\right) \mathrm{a}_{\mathrm{u}}=\mathrm{T}_{0}-\frac{1}{\mathrm{~B}(\omega)} \sum_{\mathrm{s}=1}^{\mathrm{N}} \mathrm{B}_{\mathrm{s}}^{+}(\omega) \\
& \mathrm{R}=\mathrm{R}_{0}+\sum_{\mathrm{u}=1}^{\mathrm{N}}\left(\sum_{\mathrm{s}=1}^{\mathrm{N}} \mathrm{b}_{\mathrm{s}}^{\mathrm{u}} \mathrm{c}_{\mathrm{s}}^{-}\right) \mathrm{a}_{\mathrm{u}}=\mathrm{R}_{0}-\frac{1}{\mathrm{~B}(\omega)} \sum_{\mathrm{s}=1}^{\mathrm{N}} \mathrm{B}_{\mathrm{s}}^{-}(\omega)
\end{aligned}
$$

$\mathrm{T}_{0}, \mathrm{R}_{0}$ are the transmission and reflection coefficients of the transmission line without microresonators;

$$
B_{s}^{ \pm}(\omega)=
$$




$$
=\operatorname{det}\left[\begin{array}{ccccc}
b_{1}^{1} Q_{11}(\omega) & \ldots & Q_{1}^{\mathrm{D}} \sum_{\mathrm{u}=1}^{\mathrm{N}} \mathrm{b}_{\mathrm{u}}^{\mathrm{s}} \tilde{\mathrm{k}}_{\mathrm{u}}^{\mp+} & \ldots & \mathrm{b}_{1}^{\mathrm{N}} \mathrm{Q}_{\mathrm{N} 1}(\omega) \\
\mathrm{b}_{2}^{1} \mathrm{Q}_{12}(\omega) & \ldots & \mathrm{Q}_{2}^{\mathrm{D}} \sum_{\mathrm{u}=1}^{\mathrm{N}} \mathrm{b}_{\mathrm{u}}^{\mathrm{s}} \tilde{\mathrm{k}}_{\mathrm{u} 2}^{\mp+} & \ldots & \mathrm{b}_{2}^{\mathrm{N}} \mathrm{Q}_{\mathrm{N} 2}(\omega) \\
\cdot & \ldots & \cdot & \ldots & . \\
\mathrm{b}_{\mathrm{N}}^{1} \mathrm{Q}_{1 \mathrm{~N}}(\omega) & \ldots & \mathrm{Q}_{\mathrm{N}}^{\mathrm{D}} \sum_{\mathrm{u}=1}^{\mathrm{N}} \mathrm{b}_{\mathrm{u}}^{\mathrm{s}} \tilde{\mathrm{k}}_{\mathrm{uN}}^{\mp+} & \ldots & \mathrm{b}_{\mathrm{N}}^{\mathrm{N}} \mathrm{Q}_{\mathrm{NN}}(\omega)
\end{array}\right]
$$$$
\mathrm{B}(\omega)=\operatorname{det}\left[\begin{array}{ccc}
\mathrm{b}_{1}^{1} \mathrm{Q}_{11}(\omega) & \ldots & \mathrm{b}_{1}^{\mathrm{N}} \mathrm{Q}_{\mathrm{N} 1}(\omega) \\
\mathrm{b}_{2}^{1} \mathrm{Q}_{12}(\omega) & \cdots & \mathrm{b}_{2}^{\mathrm{N}} \mathrm{Q}_{\mathrm{N} 2}(\omega) \\
\cdot & . & \cdot \\
\mathrm{b}_{\mathrm{N}}^{1} \mathrm{Q}_{1 \mathrm{~N}}(\omega) & \cdots & \mathrm{b}_{\mathrm{N}}^{\mathrm{N}} \mathrm{Q}_{\mathrm{NN}}(\omega)
\end{array}\right] ;
$$$$
\tilde{\mathrm{k}}_{\mathrm{sn}}^{++}=\left(\mathrm{c}_{\mathrm{s}}^{+} \mathrm{c}_{\mathrm{n}}^{+*}\right) /\left(\omega_{0} \mathrm{w}_{\mathrm{n}}\right)=\left(\tilde{\mathrm{k}}_{\mathrm{sn}}\right)_{0} \mathrm{e}^{-\mathrm{i} \Gamma\left(\mathrm{z}_{\mathrm{s}}-\mathrm{z}_{\mathrm{n}}\right)}
$$$$
\tilde{\mathrm{k}}_{\mathrm{sn}}^{-+}=\left(\mathrm{c}_{\mathrm{s}}^{-} \mathrm{c}_{\mathrm{n}}^{+*}\right) /\left(\omega_{0} \mathrm{w}_{\mathrm{n}}\right)=\left(\tilde{\mathrm{k}}_{\mathrm{sn}}\right)_{0} \mathrm{e}^{-\mathrm{i} \Gamma\left(\mathrm{z}_{\mathrm{s}}+\mathrm{z}_{\mathrm{n}}\right)} \text {; }
$$

$\left(\tilde{\mathrm{k}}_{\mathrm{sn}}\right)_{0}$ - is the coupling coefficient (3), for one propagating wave, expressed without phase difference accounting in the transmission line.

\section{Bandstop Filters on different microresonators}

Bandstop Filters on different microresonators in the regular transmission lines represent the most interesting case from the point of view of the theory, because in this case all the resonators at the same time exchange oscillations both by propagating and by not extending waves.

We proposed that the all microresonators are excited on $\mathrm{EH}_{1 \mathrm{~m} 1}^{+}$mode [7]. The dielectric permittivity of the first kind microresonators $\varepsilon_{1 \mathrm{r}}=16$; $\mathrm{Q}_{1}^{\mathrm{D}}=10^{6} ; \quad \mathrm{m}=\mathrm{m}_{1}=20 ; \quad \Delta_{1}=\mathrm{L}_{1} / 2 \mathrm{r}_{1}=0,2 ;$ $\mathrm{k}_{1}=6,6 \cdot 10^{-5}$. The second kind of the microresonator parameters: $\quad \varepsilon_{2 \mathrm{r}}=9,6 ; \quad \mathrm{Q}_{2}^{\mathrm{D}}=2 \cdot 10^{6}$; $\mathrm{m}=\mathrm{m}_{2}=24 ; \quad \Delta_{2}=\mathrm{L}_{2} / 2 \mathrm{r}_{2}=0,2 ; \quad \tilde{\mathrm{k}}_{2}=3,4 \cdot 10^{-4}$. Here $2 r_{s}$ - is the diameter and $L_{s}$ is the height of the $\mathrm{s}$-th Disk Microresonator; $\tilde{\mathrm{k}}_{\mathrm{s}}$ - is the coupling coefficient between $\mathrm{s}$-th microresonator and the transmission line $(\mathrm{s}=1,2)$. All mutual coupling coefficients where calculated from [8].
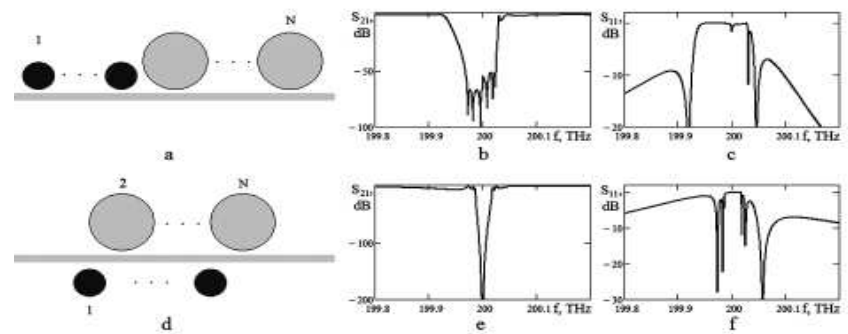

Fig. 1. Bandstop filters on different disk microresonators (a,d). S-parameter responses of the 9-section filters as functions of the frequency $(b-c, e-f)$.
Fig. 1 shows scattering parameters of the bandstop filters, consisting of 9 Disk Microresonators, calculated by the formula $(5-7)$ with help of the $(1$, 2 ). The distance between adjacent DR centers were proportional to $\lambda_{\mathrm{w}} / 4$, where $\lambda_{\mathrm{w}}$ - is the guided wavelength. As can be seen from the above dependences, proposed structures allow us to obtain different cutoff characteristics.

\section{Bandpass Filters modeling}

Bandpass filters most often used in various optical devices. In this case only the first and last resonators are coupled with transmission line: $\tilde{\mathrm{k}}_{\mathrm{st}}^{ \pm}=0$, if $\mathrm{s} \neq 1, \mathrm{~N}$ and $\mathrm{t} \neq 1$ :

$$
\begin{gathered}
\mathrm{B}_{\mathrm{s}}^{ \pm}(\omega)= \\
=\operatorname{det}\left[\begin{array}{ccccc}
\mathrm{b}_{1}^{1} \mathrm{Q}_{11}(\omega) & \ldots & \mathrm{Q}_{1}^{\mathrm{D}} \mathrm{b}_{\mathrm{N}, 1}^{\mathrm{s}} \tilde{\mathrm{k}}_{\mathrm{N}, 1,1}^{ \pm+} & \ldots & \mathrm{b}_{1}^{\mathrm{N}} \mathrm{Q}_{\mathrm{N} 1}(\omega) \\
\mathrm{b}_{2}^{1} \mathrm{Q}_{12}(\omega) & \ldots & 0 & \ldots & \mathrm{b}_{2}^{\mathrm{N}} \mathrm{Q}_{\mathrm{N} 2}(\omega) \\
\cdot & \ldots & . & \ldots & . \\
\mathrm{b}_{\mathrm{N}}^{1} \mathrm{Q}_{1 \mathrm{~N}}(\omega) & \ldots & 0 & \ldots & \mathrm{b}_{\mathrm{N}}^{\mathrm{N}} \mathrm{Q}_{\mathrm{NN}}(\omega)
\end{array}\right]
\end{gathered}
$$

For simplicity we proposed that $\tilde{\mathrm{k}}_{\mathrm{N} 1}^{++}=\tilde{\mathrm{k}}_{11}^{-+}=\mathrm{k}_{\mathrm{L}}$; where $\mathrm{k}_{\mathrm{L}}$ - is the coupling coefficient of the $1-$ th and the $\mathrm{N}$-th microresonator with the transmission input (output) line of the filter.

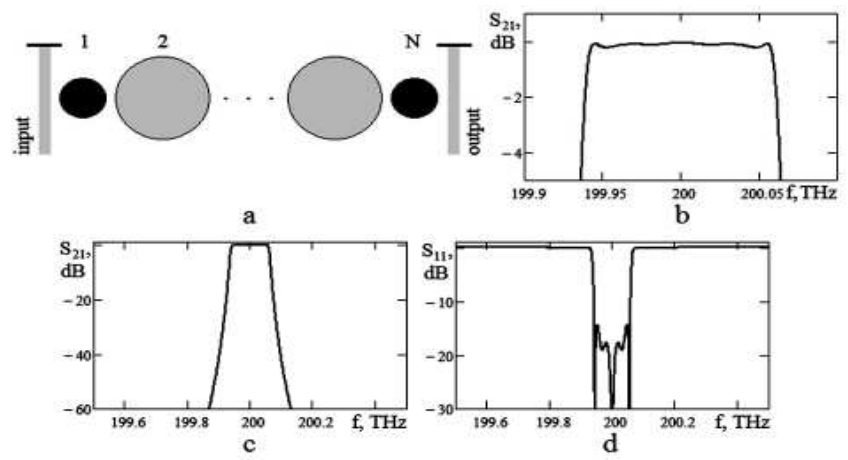

Fig.2. Bandpass filter on laterally coupled different disk microresonators (a). S-matrix responses of the 7section bandpass filter as functions of the frequency (b d). The coupling coefficients of the terminal resonators with transmission lines: $k_{L}=7 \cdot 10^{-4}$; the 1 -th and the $\mathrm{N}$ th microresonator parameters: $\varepsilon_{1 r}=16 ; \mathrm{Q}_{1}^{\mathrm{D}}=10^{6}$; $m_{1}=20$; another resonator parameters: $\varepsilon_{2 r}=9,6$; $\mathrm{Q}_{2}^{\mathrm{D}}=2 \cdot 10^{6} ; m_{2}=24$.

The fig. 2-4 show results of the calculation of bandpass filter S- parameters matrix built up on different disk microresonators with $\mathrm{HE}_{1, \mathrm{~m}, 1}^{+}$mode. The mutual coupling coefficients also where obtained from [8]. 


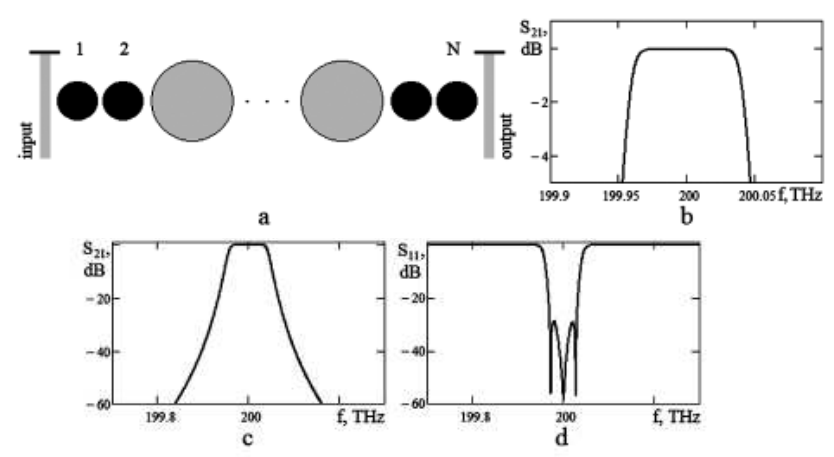

Fig.3. Bandpass filter symmetrical structure on laterally coupled different disk microresonators (a). S-matrix responses of the 7-section bandpass filter as functions of the frequency $(b-d)$. The coupling coefficients of the terminal resonators with transmission lines: $k_{L}=6 \cdot 10^{-4}$; the 1,2-th and the $\mathrm{N}-1, \mathrm{~N}$-th microresonator parameters: $\varepsilon_{1 r}=16 ; \mathrm{Q}_{1}^{\mathrm{D}}=10^{6} ; m_{1}=20$; another resonator parameters: $\varepsilon_{2 r}=9,6 ; \mathrm{Q}_{2}^{\mathrm{D}}=2 \cdot 10^{6} ; m_{2}=24$.

It's seen, that in consequence of rapidly coupling coefficients decrease [8], all S-parameters are symmetrical functions on the frequency. As we used a large number of resonators, the $\mathrm{S}_{21}$ squareness was obtained well.

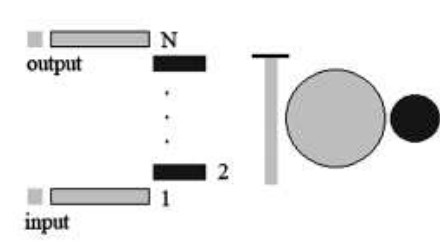

a

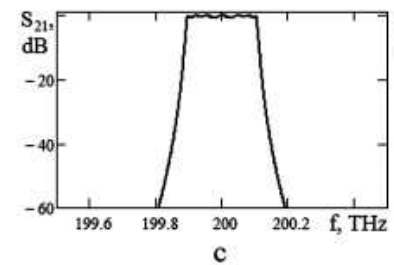

c

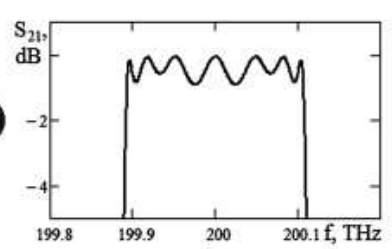

b

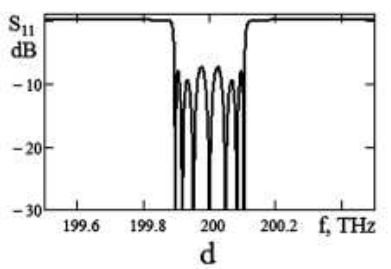

Fig.4 Bandpass filter on vertically coupled disk microresonators (a). S-matrix responses of the 7-section bandpass filter as functions of the frequency $(b-d)$. The coupling coefficients of the terminal resonators with transmission lines: $k_{L}=5 \cdot 10^{-4}$; microresonator parameters are $\varepsilon_{1 r}=9,6 ; \mathrm{Q}_{1}^{\mathrm{D}}=2 \cdot 10^{6} ; \varepsilon_{2 r}=16 ; \mathrm{Q}_{2}^{\mathrm{D}}=10^{6}$.
The best result for the vertically located disk microresonators was obtained for the structure shown in Fig. 4, a.

\section{Conclusion}

A scattering theory on different Optical Microresonator systems based on perturbation theory has been expanded.

New definitions of coupling coefficients for the different microresonators in the transmission line are presented.

New structures of the bandstop and bandpass filters on different microresonators are proposed.

The S-parameters of the filters are investigated.

\section{References}

[1] Marchetti R., Vitali V., Lacava C., Cristiani I., Giuliani G., Muffato V., Fournier M., Abrate S., Gaudino R., Temporiti E.,

Carroll L., Minzioni P. Low-Loss Micro-Resonator Filters Fabricated in Silicon by CMOS-Compatible Lithographic

Techniques: Design and Characterization // Applied Sciences, - 2017, vol. 7, № 174; doi:10.3390/app7020174. PP. 1-11

[2] Schwelb O., Frigyes I. Vernier operation of series coupled optical microring resonator filters // Microwave and optical technology letters 2003. - vol. 39. - №4. -PP.257-261.

[3] Popović M. A., Manolatou C., Watts M. R. Coupling-induced resonance frequency shifts in coupled dielectric multi-cavity filters // Optics express, - 2006, - vol. 14, - №. 3. PP. 1208 - 1222.

[4] Preu S., Schwefel H. G. L., Malzer S., Dohler G. H., Wang L. J., Hanson M., Zimmerman J. D., Gossard A. C. Coupled whispering gallery mode resonators in the Terahertz frequency range // Optics Express. - 2008. - 12 May. vol. 16, №. 10. PP. 7336-7343.

[5] Khalil H., Bila S., Aubourg M., Baillargeat D., Verdeyme S., Puech J., Lapierre L., Delage C., Chartier T. Topology Optimization of Microwave Filters Including Dielectric Resonators // Proceedings of the 39th European Microwave Conference. - Rome, Italy, - 2009. - PP. 687 690.

[6] Wang H., Liu S., Chen L., Shen D., Wu X. Dual-wevelenghth single-frequency laser emission in asymmetric coupled microdisks // Scientific Reports. - 2016, - DOI:10.1038/srep38053. PP. 1-7.

[7] Ilchenko M.Ye., Trubin A.A. Electrodynamics' of Dielectric Resonators. - Kyiv.: Naukova Dumka, 2004, 265 p. [In Russian].

[8] Trubin A.A. Coupling coefficients of different Disk Microresonators with Whispering Gallery Modes // Bulletin of NTUU "KPI" ser. Radiotechnique, Radioaparatus Building. - 2017. - №66. - P.37-45.

Received in final form on May 17, 2017 


\section{Трубін О.O.}

\section{Моделювання оптичних фільтрів на різних дискових мікрорезонаторах з коливаннями шепочучей галереї}

Проблематика. Сьогодні подальше підвищення швидкості обробки та передавання інформації пов'язується з розробкою гібридних інтегральних схем, яки об'єднують в собі електричні та оптичні компоненти. Одної із важливих складових частин майбутніх оптичних інтегральних схем є фільтри, яки зручно виконувати із так званих дискових мікрорезонаторів з коливаннями шепочучей галереї. Технічно задача виготовлення таких фільтрів в інфрачервоному та навидь у видимому діапазонах довжин хвиль вирішена, але розрахунок параметрів та настройка багатоланкових фільтрів неможлива без подальшого розвитку теорії їх проектування. Розвиток цей теорії базується на електродинамічному моделюванні процесів, яки відбуваються у складних системах зв'язаних мікрорезонаторів, зв'язаних також і з лінією передачи. В наступний час дослідження фільтрів, побудованих на різних мікрорезонаторах не проводилось.

Мета досліджень. Метою досліджень є розробка теорії розсіювання електромагнітних хвиль інтегральних оптичних ліній на системах зв'язаних між собою різних оптичних мікрорезонаторів з коливаннями шепочучей галереї. Розробка математичних моделей фільтрів, виконаних із застосуванням різних дискових мікрорезонаторів. Дослідження нових структур зв'язаних мікрорезонаторів з прийнятними характеристиками розсіювання.

Методика реалізації. Для побудови математичної моделі фільтрів застосовано приблизне вирішення системи рівнянь Максвела, засноване на застосуванні теорії збурень. Застосуванні теорії збурень дозволило знайти вирішення задачі розрахунку S - матриці фільтра у аналітичному вигляді.

Результати досліджень. Розроблена електродинамічна модель розсіювання хвиль оптичної лінії на системі зв'язаних мікрорезонаторів різної форми і виконаних із різного діелектрика. Досліджені нові структури мікрорезонаторів яки реалізують смугові та режекторні фільтрі та розраховані їх характеристики розсіювання.

Висновки. Розширена теорія розсіювання електромагнітних хвиль на системах різних зв'язаних оптичних мікрорезонаторів. Дано нове визначення коефіцієнтів зв'язку різних мікрорезонаторів. Побудовані нові моделі фільтрів.

Ключові слова: Інфрачервоний діапазон; інтегральна оптика; оптичний фільтр; смуговий фільтр; режекторний фільтр; мікрорезонатор.

\section{Трубин А.А.} галлереи

Моделирование оптических фильтров на различных дисковых микрорезонаторах с колебаниями шепчущей

Проблематика. В настоящее время дальнейшее повышение скорости обработки и передачи информации связывается с расработкой гибридных интегральных схем, объединяющих в себе электрические и оптические компоненты. Одной из важных составляющих частей будущих оптических интегральных схем являются фильтры, которые удобно выполнять, используя так называемые дисковые микрорезонаторы с колебаниями шепчущей галлереи. Технически задача изготовления подобных фильтров в инфракрасном и даже в видимом диапазоне длин волн решена, однако расчет параметров и настройка многозвенных фильтров невозможна без дальнейшего развития теории их проектирования. Развитие такой теории основывается на электродинамическом моделировании процессов, которые происходят в сложных системах связанных микрорезонаторов, связанных также и с линией передачи. В настоящее время исследование фильтров, построенных на различных микрорезонаторах не проводилось.

Цель исследований. Целью исследований является построение теории рассеяния электромагнитных волн интегральных оптических линий передачи на системах связанных между собой различных оптических микрорезонаторов с колебаниями шепчущей галлереи. Разработка математических моделей фильтров, выполненных с применением различных дисковых микрорезонаторов. Исследование новых структур связанных микрорезонаторов с приемлемыми характеристиками рассеяния.

Методика реализации. Для построения математической модели фильтров использовано приближенное решение уравнений Максвелла, основанное на применении теории возмущений. Применение теории возмущений позволило найти решение задачи расчета $\mathrm{S}$ - матрицы фильтра в аналитическом виде.

Результаты исследований. Разработана электродинамическая модель рассеяния волн оптической линии на системе связанных микрорезонаторов разной формы и выполненных из разного диэлектрика. Исследованы новые структуры микрорезонаторов, реализующих полосовые и режекторные фильтры и рассчитаны их характеристики рассеяния.

Выводы. Расширена теория рассеяния электромагнитных волн на системах разных связанных оптических микрорезонаторов. Дано новое определение коэффициентов связи разных микрорезонаторов. Построены новые модели фильтров.

Ключевые слова: инфракрасный диапазон; интегральная оптика; оптический фильтр; полосовой фильтр; режекторный фильтр; микрорезонатор. 